\title{
Better to Return Whence We Came
}

\section{Ema Sullivan-Bissett ${ }^{1}$}

Accepted: 23 January 2022 / Published online: 3 March 2022

(c) The Author(s) 2022

I argue that David Benatar's anti-natalism leads to pro-mortalism (the view that it is better to cease to exist) because the human predicament as he describes it is a fate worse than death. Thus, continued existence in such a predicament is not preferable to an exit from it. I revisit my earlier argument for the claim that Benatar's (2006) asymmetry between pleasure and pain paved the way for pro-mortalism unless Epicureanism about death is ruled out. I reply to Benatar's response to that argument. I then turn to Benatar's (2017) characterization of the human predicament and suggest that that also leads to pro-mortalism. I respond to three arguments from Benatar that seek to block the move from our predicament to pro-mortalism. I conclude that if Benatar is right about the predicament we find ourselves in, it is better for most people to return whence they came. ${ }^{1}$

\section{Preliminaries}

Benatar motivates his anti-natalism with two arguments: the argument from asymmetry and the argument from the appalling quality of our lives. Let us start with the first.

The asymmetry has it that existing people experience pleasure, which is good, and pain, which is bad. For each case of non-existence, there is an absence of pain, which is good (even if that good is not enjoyed by anyone), and an absence of pleasure, which is neither good nor bad (such absences are bad only if there is somebody for whom the absence is a deprivation). As Elizabeth Harman puts it:

\footnotetext{
${ }^{1}$ I take this language from Sophocles (Oedipus at Colonus, cited in David Benatar), Better Never to Have Been: The Harm of Coming Into Existence (New York: Oxford University Press, 2006), p. 212.

Never to have been born is best

But if we must see the light, the next best

Is quickly returning whence we came.

Ema Sullivan-Bissett

e.1.sullivan-bissett@bham.ac.uk

1 University of Birmingham, Birmingham, UK
} 
By bringing someone into existence, one harms her by causing all the bad aspects of her life. By bringing someone into existence, one does not benefit her at all by causing the good aspects of her life. ${ }^{2}$

I have previously argued that Benatar's asymmetry leads to pro-mortalism, the view that it is better to cease existing than continue existing. ${ }^{3}$ If that is right, I suggested, Benatar's asymmetry leads us to the view that suicide is preferable to continued existence. There is, admittedly, a move here from non-existence being preferable to existence, to a particular route (suicide) to non-existence being preferable to existence. And there is, of course, room to deny the particular route claim even whilst accepting the non-existence claim. For example, if the particular route to one's demise had some feature which trumped any benefits of non-existence and costs of existence, then perhaps the asymmetry would call for non-existence as a destination but not for one to pilot the journey. Might Benatar exploit the gap between the claims of non-existence and particular route? Candidate approaches for doing so might include holding suicide to be so morally egregious that it trumps any considerations which might otherwise motivate it. Another option might relate to the possible ramifications of suicide for the afterlife one is likely to enjoy, or one's relationship with God. Benatar is not in the business of exploiting the gap in these ways. He is clear that although suicide is sometimes morally wrong, it is not always, ${ }^{4}$ and his argument against the 'theistic gambit' with respect to life's meaning(lessness) ${ }^{5}$ suggests that a similar gambit in this context would not be indulged (he also notes in his discussion on suicide that he will assume that there is no afterlife ${ }^{6}$ ). I proceed then with a benign equivocation between it being better for one not to exist and it being better to end one's life, speaking in the former terms where possible.

One more clarification is called for. I am understanding pro-mortalism strictly as defined earlier, as the view that it is better to cease to exist. It is this view which I think is a natural endpoint of each of Benatar's two arguments for anti-natalism. A slightly different version of pro-mortalism might have it that ceasing to exist is morally or rationally required..$^{7}$ I will presume that these versions are different insofar as something can be best for us even if it is not thus morally or rationally required of us to bring that thing about. This is especially important to keep in mind when we turn

\footnotetext{
${ }^{2}$ Elizabeth Harman, "Critical Study: David Benatar. Better Never to Have Been: The Harm of Coming into Existence," Nô̂s, Vol. 43, No. 4 (2009): 776-785, p. 776.

3 Rafe McGregor and Ema Sullivan-Bissett, "Better No Longer to Be," South African Journal of Philosophy, Vol. 31, No. 1 (2012): 55-68.

4 David Benatar, The Human Predicament: A Candid Guide to Life's Biggest Questions. (New York, NY: Oxford University Press, 2017), p. 198.

5 Ibid., 36-45.

6 Ibid., 168.

7 For an argument that suicide is not even rationally evaluable, see Christopher Cowley, "Suicide is Neither Rational nor Irrational," Ethical Theory and Moral Practice, Vol. 9 (2006): 495-504. If Cowley is right the kind of pro-mortalism I have in mind is unaffected.
} 
to the importance of subjective evaluations of one's quality of life (§6). Let us begin then by briefly revisiting my earlier argument, and responding to Benatar's reply. ${ }^{8}$

\section{Death is a Harm}

In a previous paper I suggested that Benatar's asymmetry got us to pro-mortalism since when somebody ceases to exist "the result is: an absence of pain, which is good; and an absence of pleasure, which is not bad." Of course, Benatar has an answer to this quick piece of click bait, which is built into his asymmetry: the absence of pleasure is not bad unless there is somebody for whom the absence is a deprivation. A natural thought then is that when a person dies they are thus deprived of future pleasures, and the absence of those pleasures is $\mathrm{bad}$. In which case the most that could be said when we turn to whether it is better for someone to cease existing is that Benatar's asymmetry raises a question concerning whether the badness of being deprived of future goods outweighs the badness of continued existence. However, that that question might be the basis of whether it is better to cease to exist is hardly controversial, indeed, it may well be exactly such a weighing procedure that those who die by suicide engage in. The theoretical pay off would be Benatar's asymmetry framing or elucidating an already recognized form of deliberation about one's life and death. Indeed, Gerald Harrison notes that ' $[\mathrm{t}] \mathrm{o}$ think that Benatar's [asymmetry] implies pro-mortalism is just to ignore the asymmetry thesis that is central to it'. ${ }^{10}$ However, as I will now argue, to think that the asymmetry does not imply pro-mortalism is just to ignore the possibility that one is not deprived by death.

The above characterization of the situation and the asymmetry's benign relationship to ending one's life only stands insofar as one is willing to endorse a view of death on which death is bad for the person who dies because it deprives her of future goods. This deprivation moves the absence of pleasures from not bad to bad, and distinguishes that absence for the never-existent compared to the no-longer-existent. Accordingly, there would be no grounds from the quarters of possible pleasures for bringing people into existence, since the non-experience of those possible pleasures is neither good nor bad. But there would be grounds from the quarters of possible pleasures for not ending existence, since in doing so we would create a deprivation, which is bad. That death deprives the one who dies then is crucial to Benatar's asymmetry not leading to pro-mortalism.

However, on one familiar if unpopular view of death, which we can trace back to Epicurus, death is not bad for the one who dies:

\footnotetext{
${ }^{8}$ David Benatar, "Every Conceivable Harm: A Further Defence of Anti-Natalism," South African Journal of Philosophy, Vol. 31, No. 1 (2012): 128-64.

9 McGregor and Sullivan-Bissett, op. cit., pp. 56-7.

${ }^{10}$ Gerald Harrison, "Antinatalism, Asymmetry and an Ethics of Prima Facie Duties," South African Journal of Philosophy, Vol. 31, No. 1 (2012): 94-103, p. 101, fn. 11.
} 
[W] hen we are, death is not come, and, when death is come, we are not. It is nothing, then, either to the living or to the dead, for with the living it is not and the dead exist no longer. ${ }^{11}$

If death is not bad and we are not deprived by it, the path to pro-mortalism opened up by Benatar's asymmetry cannot be blocked by appeal to deprivation. Benatar seems to recognize this and spends some time arguing against a view of death on which it is not bad. ${ }^{12}$ I have previously replied to those arguments by suggesting that they can all be answered by the Epicurean. ${ }^{13}$

Before turning to Benatar's response to those replies, it is worth noting that Epicureanism about death is not a bygone position, of interest only to historians of philosophy. If it were we might happily recognise that Benatar's blocking of the path to pro-mortalism is hostage to the falsity of this view, but if no one took it seriously anyway, that fact needn't be anything to lose sleep over. However, although far from orthodoxy, Epicureanism nevertheless has some modern day proponents. ${ }^{14}$ It is a live option which, if true, facilitates the move from Benatar's asymmetry to promortalism. And so, contrary to Benatar's claim that refuting it is not required, ${ }^{15}$ or that it is merely 'fine for the seminar room,' ${ }^{16}$ its status as a live option represents a challenge for his view. If Epicureanism about death is true, then one is not deprived of future pleasures when one ceases to exist, one's death is not bad for one. By the asymmetry then, pro-mortalism follows. Let us turn to Benatar's earlier replies to this point.

He first points out that if his view plus some other view implies pro-mortalism that is not to undermine his claim that his view alone does not imply pro-mortalism. That is, "[t]o say that view $\mathrm{X}$ combined with view $\mathrm{Y}$ yields view $\mathrm{Z}$ is not to say that X entails or implies Z." ${ }^{17}$ But, as Benatar points out, this could seem like a logical nicety if the Epicurean view were true. Let us reflect then on the status of Epicureanism in the context of Benatar's anti-natalism. Of course, we should recognize that almost all philosophical claims proceed with a background of relevant truths in mind. To take two examples: detailed debates about the ontology of implicit bias are downstream of the claim that solipsism is false. Discussions regarding the nature of epistemic normativity would be derailed if we required discussants to refute

\footnotetext{
11 Epicurus, "Death is Nothing to Us," in Linda Zagzebski, and Timothy D. Miller, eds. Readings in Philosophy of Religion: Ancient to Contemporary (est Sussex: Blackwell Publishing Ltd, 2009), 405-406, p. 406.

12 Benatar, Better Never to Have Been, op. cit., pp. 214-17.

13 McGregor and Sullivan-Bissett, op. cit., pp. 59-63.

14 See e.g. Simon Cushing, "Don't Fear the Reaper: An Epicurean Answer to Puzzles about Death and Injustice," in Kate Woodthorpe (ed.), Layers of Dying and Death (Oxford: Inter-Disciplinary Press, 2007), 117-127; David Suits, "Why Death is Not Bad for the One Who Died," American Philosophical Quarterly, Vol. 38, No. 1 (2001): 69-84; and to some extent, Byron J. Stoyles, "Challenging the Epicureans: Death and Two Kinds of Well-Being," The Philosophical Forum, Vol. 42, No. 1 (2011): 1-19; and Christopher Williams, "Death and Deprivation," Pacific Philosophical Quarterly, Vol. 88 (2007): 265-83.

15 Benatar, "Every Conceivable Harm", op. cit., p. 157.

16 Benatar, The Human Predicament, op. cit., p. 127.

17 Ibid., 158.
} 
eliminativism about belief. In these cases, theoretical inconvenience is overcome by legitimately parking positions sufficiently far from the starting terms of the debates in question. However, not all parking of inconvenient positions is legitimate. Consider those interested in what kind of mental state is constitutive of implicit bias, or the relationship between bias and behaviour. Such theorists $d o$ have a theoretical duty to engage with the recent scepticism concerning the very existence of implicit bias. Similarly, those concerned with the precisification of a guiding epistemic norm of belief ought to take seriously the family of views which have it that belief is essentially non-normative, and that there is, in fact, no such norm.

In the context of Benatar's philosophical programme, is Epicureanism about death analogous to solipsism in discussions of implicit bias, and eliminativism in the context of epistemic normativity? Or is it more like scepticism about implicit bias, and error theories about epistemic normativity? That is, can we park Epicureanism about death, taking its falsity for granted when in the business of defending anti-natalism from the possible bridge to pro-mortalism? Or is it incumbent on anti-natalists to establish its falsity if they wish to avoid their views motivating pro-mortalism?

Although I cannot determine the answer to this here, I'm inclined to the second option, for two reasons. First, Benatar's overall approach is, as he recognizes, replete with claims concerning the nature of our lives and the ethics of procreation that are, to put it mildly, unorthodox. Given that, it would be strange to nevertheless help oneself to the presumed falsity or irrelevance of a similarly unorthodox view on a nearby topic which has significant ramifications for his position. Second, given that Benatar spends some time seeking to refute Epicureanism, ${ }^{18}$ we can take it that he doesn't consider Epicureanism to stand to his view as solipsism does to the ontology of implicit bias, or eliminativism does to the normativity of belief. It is rather a view to be reckoned with.

Benatar's second point is that very few people think that the Epicurean view of death is true. ${ }^{19}$ We are not, though, given a reason to give much weight to this observation. It might be thought that positions with minority status are more legitimately parked in the way described above, but I have already noted why that would not be appropriate in this case. There is also a clear symmetry here that ought not go unremarked: Benatar's view that existence is a harm shares the feature of being believed by very few folk. This is something he recognizes which is why the view is often accompanied by an explanation of why we tend not to believe it. ${ }^{20}$ This works to disarm she who points to the bare unpopularity of a view as suggestive of its falsity, or at least, its implausibility. If we can explain why our view might not be widely believed in spite of its truth, or even better, if our view predicts its own unpopularity, it is thus to some extent inoculated from that very unpopularity having

\footnotetext{
18 Benatar, Better Never to Have Been, op. cit., pp. 213-18; The Human Predicament, op. cit., pp. 96-136.

19 Benatar, "Every Conceivable Harm", op. cit., p. 158.

20 Benatar, Better Never to Have Been, op. cit.; "Every Conceivable Harm", op. cit.; The Human Predicament, op. cit.
} 
any epistemic lessons to impart. It is worth noting then that just like Benatar's own unpopular views, reasons have been offered for why folk do not think Epicureanism about death is true even though it is.

David Suits has given an explanation of why we take death to be bad by appeal to our common experience of injuries:

The more severe the injury, the greater the pain, and the longer it will take to recover. [...] It is easy to extend such observations to include death, which is then thought of as the most severe injury because the entire organism permanently fails and no recovery at all is possible. On this psychological slippery slope, if mild damage is a mild harm, then death must be the greatest of harms. ${ }^{21}$

(Following Benatar, my discussion is in terms of bads not harms, and so we can understand Suits as explaining why we take death to be a serious bad. $^{22}$ ) Just like Benatar's work on Pollyannaism and other cognitive biases as explanatory of why we find his position implausible, ${ }^{23}$ here we have an explanation of the unpopularity of the Epicurean view of death. In light of these kinds of consideration, the bare unpopularity of these views is less able to get an argumentative hold.

Benatar's third point is that if Epicureanism were true, it would follow that killing somebody would not be bad for the person, which is an even harder view to accept than his anti-natalism. ${ }^{24}$ However, that claim about the relative intuitiveness of positions does not - at least not without some further premises - suggest anything about the epistemic status of the Epicurean position. And, like the central idea that death is not bad, we can explain why it is widely thought that bringing about the death of a person is bad for them by appeal to similar considerations as those raised by Suits. If death is bad for someone, then murder (which brings about death) is bad for them too. But if the badness of murder is based on the badness of death, we are able to explain why folk mistakenly hold onto the latter claim, and thus also explain their commitment to the former. We might also challenge the idea that the Epicurean cannot accommodate the idea that murder is bad (even though death is not bad for the victim). This has been attempted recently by Simon Cushing, who moves from thinking in terms of harms to wrongs. He argues that one can be wronged by a death one is not harmed by, because the victim "has the right of self-determination that [the murderer's] action robs of its essential basis". ${ }^{25}$ It is unclear whether Cushing thinks it is bad for one to suffer a wrong, but a view of this kind might have the resources to retain the badness of murder, without that spreading to our characterization of death simpliciter.

\footnotetext{
21 Suits, op. cit., pp. 81-2.

22 See Benatar, The Human Predicament, op. cit., pp. 96-97.

23 See Benatar, Better Never to Have Been, op. cit., pp. 64-9, and Benatar, The Human Predicament, op. cit., pp. 67-71.

24 Benatar, "Every Conceivable Harm", op. cit., p. 158. See also Benatar, The Human Predicament, op. cit., pp. 124-125.

${ }^{25}$ Cushing, op. cit, p. 136.
} 
Benatar's final point is that if one were an Epicurean, one would not find promortalism alarming. ${ }^{26}$ Again though, this is not an argument against Epicureanism, but a dialectical point about the how unsavory the putative consequence of Benatar's view is when it fails to rule out Epicureanism. If it is true that Epicureans would find pro-mortalism entirely reasonable that is fine by me; my point was and is only that Benatar's asymmetry leads to pro-mortalism, but that point was never put in the spirit of reductio. Indeed, Benatar notes that through personal correspondence he learned that one of the authors of my earlier paper took the argument from pro-mortalism to be a reductio, whilst the other took it to be merely of theoretical interest. ${ }^{27}$ I am the other author, and if Benatar's anti-natalism turns out to have a surprising or unintuitive consequence, that is fine by me.

More recently Benatar has pointed out that the Epicurean has no one for whom death would be good: "[j] ust as Epicureans cannot think that death is bad, so they cannot think that death is good (or even less bad)." ${ }^{28}$ Space constraints prevent a full discussion of this point, suffice to say for now that the Epicurean can help herself to the component of Benatar's asymmetry which has it that the absence of pain is good, even if there is nobody to enjoy that good. Even Epicureans can talk about what is better, just as Benatar talks about it being better never to have come into existence (even though there is nobody for whom it is better).

Overall then, Benatar's reason for denying that we get to pro-mortalism from his asymmetry requires the falsity of Epicureanism about death, which has not been shown. I turn now to Benatar's second argument for anti-natalism, which is based on the appalling quality of human lives. I will argue that from this argument we also arrive at pro-mortalism.

\section{The Human Predicament and Pro-mortalism}

The claim that life is awful is given a book length defence in Benatar's The Human Predicament. To summarise, the human condition is a "tragic predicament" from which we cannot escape. ${ }^{29}$ This can be seen by reflection on its inevitable features.

First, our lives have no meaning from the perspective of the universe, ${ }^{30}$ and at best they have very limited terrestrial meaning. As Katie Mack puts the point:

Whatever legacy-based rationalization we use to make peace with our own personal deaths (perhaps we leave behind children, or great works, or somehow make the world a better place), none of that can survive the ultimate destruction of all things. At some point, in a cosmic sense, it will not have

\footnotetext{
26 Benatar, "Every Conceivable Harm", op. cit., p. 158.

27 Ibid., 158.

28 Benatar, The Human Predicament, op. cit., p. 126.

29 Ibid., 1.

30 Ibid., 35.
} 
mattered that we ever lived. The universe will, more likely than not, fade into a cold, dark, empty cosmos, and all that we've done will be utterly forgotten. ${ }^{31}$

Benatar takes it to be "deeply disturbing" that our lives are meaningless from the cosmic perspective. ${ }^{32}$ Despite our trials and tribulations, the ups and the downs, we are left facing "the pointlessness of the entire human endeavor." 33

Second, the overall quality of our lives is appalling. Whilst recognizing that there is huge variation in the quality of human lives, Benatar argues that even the best of those lives are not good ones. On the best of days each of us experiences hunger and thirst, the relief of which leads to the discomfort of full bladders and bowels. Relieving that is sometimes easy enough, but often is not when and where one would prefer. Further, we are often not at a comfortable temperature, but are either too warm or too cold, and we spend a lot of our waking hours feeling tired. ${ }^{34}$

These are the best of days. But many of our days are not the best of days, and so involve all of the above plus additional physical and psychological discomfort and pain. From minor illnesses affecting basically everyone, to the menstrual pain, discomfort, and inconvenience suffered by women, which ends only when they go through the often highly symptomatic and difficult process of menopause. Many people also have chronic illnesses, which can be highly disabling, painful, and lifelimiting. There are also the common psychological hurdles: form filling, queuing, inefficiency, job dissatisfaction, unrequited love, unfulfilled desires and ambitions, and, if we are among the lucky ones: the loss of our elders. ${ }^{35}$

Then of course there are the horrifying possibilities we face, which, when added altogether, the "cumulative risk of something horrific occurring to each one of us is simply enormous." 36 To name just a handful of possible fates, we each face the possibility of becoming victim to serious burns, paralysis, cancer, depression, rape, abduction, torture, and murder. ${ }^{37}$ Taken as a whole, human life is "an unenviable condition." 38

Against this assessment, Saul Smilansky has argued that the relative infrequency of suicide among humans is "a great embarrassment" for Benatar's claims about the awfulness of human lives. ${ }^{39}$ However, as I have alluded to already, Benatar's view has the resources to accommodate its prima facie implausibility and its related unpopularity. Part of Benatar's discussion of the awfulness of life concerns the fact that we are prone to overestimating the quality of our lives, given a host of cognitive

\footnotetext{
31 Katie Mack, The End of Everything (Astrophysically Speaking). New York: Scribner (2020), p. 206.

32 Benatar, The Human Predicament, op. cit., p. 36.

33 Ibid., 63.

34 Ibid., 71.

35 Ibid., 72-3.

36 Ibid., 73.

37 Ibid., 73-5.

38 Ibid., 91.

39 Saul Smilanksy, "Life is Good," South African Journal of Philosophy, Vol. 31, No. 1 (2012), pp. 69-78, p. 71 .
} 
biases, including optimism bias, adaptation, and comparison. ${ }^{40}$ If we corrected for such biases, we would see that the quality of our lives is in fact very poor. To simplify: if suicide occurs based on the judgement that one's life is overall bad, it is a prediction of Benatar's position that this would be an infrequent event. Indeed, he is explicit that our being self-deceived about the quality of our lives is "unsurprising from an evolutionary perspective because it militates against suicide and in favour of pro-creation." ${ }^{41}$ In addition, taking one's life is an extremely difficult thing to do, even for those who do not want to live anymore; Benatar takes this to be part of the explanation for why contemplation of suicide is more common than attempt or completion. ${ }^{42}$ In sum, there is no embarrassment for Benatar here.

Third, all lives end in death and annihilation. These are taken to be separate bads which are certain for every life. As we have already seen, the badness of death is based on the idea that death deprives us of future goods. Annihilation, understood as the total and irreversible obliteration of a person, is a bad that survives those cases in which a person is not deprived by their death. Benatar's example is of a soldier's death which is overdetermined (had he not died in a given instant, he'd have died moments later). The death does not deprive the soldier of any future goods, but his death is nonetheless bad. We can account for this once we recognize that the badness of death is not exhausted by deprivation but comes with the additional bad of annihilation. ${ }^{43}$ (Although others have argued that such cases can be accommodated by the deprivation account. ${ }^{44}$ )

Against this background of human lives as horrendous, Benatar is, unsurprisingly, highly permissive about the contexts in which suicide is better than continued existence. However, he stops short of saying that suicide is always preferable to continued existence. He has at least three reasons for this. The first is that death is part of the human predicament, and so suicide which results in death cannot be a solution to it. The second is that the annihilation which comes from death is something which, all else equal, is best delayed. And the third is that for those who already exist, subjective appraisals of one's quality of life can trump objective ones which would suggest that suicide is better than continued existence. I respond to these points shortly. ${ }^{45}$ Two further reasons for denying that suicide is always the best option if

\footnotetext{
40 See Benatar, Better Never to Have Been, op. cit., pp. 64-69, and Benatar, The Human Predicament, op. cit., pp. 67-71.

41 David Benatar, "Still Better Never to Have Been: A Reply to (More of) My Critics," Journal of Ethics, Vol. 17 (2013): 121-51, p. 146. See also "Every Conceivable Harm”, op. cit., p. 154.

42 Benatar, The Human Predicament, op. cit., p. 177.

43 Ibid., 132.

44 Christopher Wareham, "Deprivation and the See-saw of Death," South African Journal of Philosophy, Vol. 28, No. 1 (2009): 246-56, pp. 252-253.

45 Some of the arguments in what remains of the paper were presented in fetal form in my review of The Human Predicament (Ema Sullivan-Bissett, "Review of David Benatar, The Human Predicament: A Candid Guide to Life's Biggest Questions," The American Journal of Bioethics, Vol. 18, No. 7 (2018): 4-6). Harman, op. cit., p. 784, also makes the point that pro-mortalism follows from Benatar's claims about the poor quality of our lives, although she does so relatively briefly. It has also been argued more generally that it follows from nihilism (no lives are, all things considered, worth living) that it cannot be better to continue to exist than to cease to exist (David Matheson, "The Incoherence of Soft Nihilism," Think, Vol. 16 (2017): 127-135.
} 
Benatar is right about the human predicament are worth noting before I do so. One reason might be found in reflecting on the other-directed obligations we have not to take our own lives. ${ }^{46}$ I put this aside because I am interested in what is better for the person whose life is ended, discussion of blocking pro-mortalism via reflection on obligations to others is for another time. Another reason might draw our attention to the fact that for many lives, the worst parts come later, and so "[i]t thus might make sense for people who are still in the better part of their lives to delay suicide until the worst aspects begin to manifest themselves." ${ }^{47}$ I say two things in response. Firstly, this strikes me as a point about the extent of one of the features of our predicament across time. That is, the level at which our lives are appalling is a non-static feature of them - for many people, they are more appalling later in life. However, at least some of the more mundane qualities that make for appalling lives are present early on (form-filling, queuing, full bladders and bowels, and so on). So even if lives tend to become worse over time and our earlier lives are less bad, as Benatar puts it, "[s]omething's being very bad is not negated by the possibility that things could still be worse." 48 Second, even if our earlier lived days are only minimally appalling in terms of quality, even those days are ones marred by the other components of our predicament (meaninglessness, eventual death, and annihilation). If we put aside the foregoing considerations, at best there may be a tipping point when one has more bad to miss out on by ceasing to exist than the goods one would be thus be deprived of. If our lives were not overall bad in their earlier parts, then pro-mortalism would simply be true for different people at different times. Overall, there is little mileage in the fact that our lives are worse towards the end if one is seeking to block the path from the human predicament to pro-mortalism.

\section{Death is Part of the Human Predicament}

We can understand the role of death in blocking pro-mortalism in two ways. The first is that death being bad means that suicide is no solution to our predicament. ${ }^{49}$ Earlier I argued that Benatar has not successfully ruled out Epicureanism about death. If death is not bad for the person who dies, presumably it would not be properly characterized as part of the human predicament. I will assume for the sake of argument that death is part of our predicament. The second role that death plays in blocking pro-mortalism is its not being a solution on the grounds that it does not solve all the components of our predicament. ${ }^{50} \mathrm{I}$ will focus mostly on this line of argument, although the badness of death will enter towards the end of this section.

Hastening one's death is said not to be a solution to the human predicament because doing so does not solve the problem of mortality, or the fact that our lives

\footnotetext{
${ }^{46}$ Harman, op. cit., p. 784.

47 Benatar, "Still Better Never to Have Been", op. cit., p. 150.

48 Benatar, "Every Conceivable Harm", op. cit., p. 150.

49 Benatar, The Human Predicament, op. cit. 3.

50 Ibid., 2-3.
} 
have no meaning beyond limited terrestrial meaning that some of our lives might enjoy. ${ }^{51}$ Nor does it stop us from being annihilated, which, recall, is a harm independent of the harm of deprivation from death, and something which "only deepens the predicament". ${ }^{52}$ It cannot be said then that the human predicament warrants the claim that ceasing to exist is a better response to our predicament than continued existence.

However, those who consider the natural and right response to learning of our predicament to be ceasing to exist may not be swayed by the fact that doing so does not fully spare us of our predicament. Ceasing to exist need not get one out of all dimensions of the human predicament to be a reasonable response to it, or even the best response to it. Partial solutions can be both reasonable and the best.

Compare the following case: Jemma is hungry and thirsty; call this Jemma's predicament. There is no food in her house, but there is water. Whether she goes to the kitchen or the bedroom she will remain hungry, but her thirst can be satiated. It is no objection to the claim that it would be better for Jemma to drink water than remain thirsty that she will nevertheless remain hungry. Similarly, our predicament is such that there is no avoiding lack of meaning or our eventual death (and annihilation), both choosing to cease to exist and choosing to continue on keeps one facing those dimensions of the predicament. This means that one can appropriately respond to the poor quality of our lives by choosing to cease to exist.

There is one way in which this analogy might be thought inappropriate. Jemma faces a situation in which she has two unsatisfied desires, the proposed course of action will satisfy one of those desires, and so she ought therefore pursue that course even whilst recognizing that her other desire will remain unsatisfied. Whereas in the case at hand, ceasing to exist is not one yet-to-be-satisfied desire among others which can be singularly satisfied, it is rather something which would relieve one of some features of a predicament, and of course, lead to the cessation of desire altogether. For those who take this disanalogy to be argumentatively fatal, I offer a closer, although slightly artificial, case.

Jill is in an unhappy relationship which is certain to end in a few months when she moves across the world. She feels sad that she faces the trauma of a break-up, and she also feels sad that the relationship consists of arguments, verbal abuse, and a lack of affection. Part of Jill's predicament then is the trauma of a break-up, but that is no reason not to bring the break-up forward. Of course in doing so Jill does not solve her predicament, since the trauma of a break-up is part of that very predicament, but here, like Jemma's case, partial solutions can be appropriate. It is no argument against the claim that it is better for Jill to break up with her partner that doing so does not free her from all dimensions of her predicament (namely, the trauma of a break-up). It does however free her from arguments, verbal abuse, and the lack of affection from a partner. And this is the case even whilst recognizing that in ending the relationship prematurely, Jill will be deprived of the (albeit limited) goods of it. Just like human lives, Jill's relationship contains much more bad than good, and

\footnotetext{
51 Ibid., 94.

52 Ibid.
} 
so whilst recognizing that she will be deprived of some goods, and that ending the relationship prematurely does not relieve her of all dimensions of her predicament, it would nevertheless be better for her if the relationship ended.

Similarly then, although we can grant that death is part of our predicament, that does not mean that it cannot be a (albeit partial) solution to it. If life is as awful as Benatar says, ceasing to exist is entirely appropriate, even whilst recognizing that death is not a cost-free solution but is rather "the second jaw of our existential vice." ${ }^{, 53}$ But given that it releases us from the suffering of continued existence, even if it is itself a serious bad, if the human predicament is as dire as Benatar claims, it might be the best of a bad bunch of options.

\section{Annihilation is Best Delayed}

Benatar's second reason he gives for the claim that the awfulness of life does not get us to pro-mortalism is that annihilation is best delayed. ${ }^{54}$ Annihilation, our total obliteration, is an inevitable awful feature of our lives, and is a badness of death in addition to deprivation. This means that for those attracted to the idea of death as bad but who do not buy into that being grounded in deprivation, or in cases where death deprives one of no future goods, the independent badness of our annihilation could explain why death is bad.

Of course, something being bad need not mean that it is best delayed, especially if doing so prolongs one's exposure to further bads, not least the bad of anticipating the delayed bad. The calculation might change if annihilation had some additional features which means it is, all else equal, best delayed. This is indeed Benatar's claim - he argues that it is best to delay annihilation because one cannot get over it. $^{55}$

However, why think that this additional feature of the bad of annihilation is thus a reason to delay? Perhaps in cases where life is overall good but for annihilation this would make sense. But Benatar thinks that there are no such lives, rather, even when we have not been annihilated things are very bad, and there is more bad than good in our lives. Given that, why would it be good to delay the inevitability of a bad which would relieve us of other bads?

Let us return to Jill. Imagine that Jill never gets over the relationship break-up, and let us stipulate also that she knows this. Does that fact give her a reason to delay it? I don't think it does once we take into account that the relationship involves more bad than good. Even in this case where the fact that she doesn't get over it is experienced as such. We can grant that relationship break-ups and annihilation are bads we cannot get over, but that does not yet give us any reason to hold them off. As Kirsten Egestrom puts it, if annihilation "is going to be a bummer no matter when it occurs,

\footnotetext{
53 Ibid., 2.

54 Ibid., 133.

55 Ibid., 133.
} 
one may as well die early to avoid the future dis-value associated with a poor quality of life." 56

\section{Subjective Appraisals}

The final reason Benatar gives for his view not leading to pro-mortalism is that we ought to give weight to the subjective appraisals of our lives. Although these are often not rational, Benatar nevertheless takes them to be relevant in his discussion on suicide. It might be thought that if we take these evaluations too seriously we could wonder whether the impermissibility of procreation based on objective quality of the life brought into existence could be trumped by the perceived quality of the life created. And this really matters-Benatar is all too aware that most of us judge that our lives are pretty good. So if subjective assessments matter when it comes to making a judgement on whether it is better to cease existing, could we not insist that they matter when it comes to beginning life?

This is related to the hypothetical consent objection to anti-natalism which has it that procreation is permissible since potential procreators "can [...] reasonably rely on some notion of hypothetical consent on the part of the ones created." ${ }^{\text {However, }}$ hypothetical consent in the procreation case is, at the very least, complicated. Seana Shiffrin notes that there are people who regret being born, and those who are ambivalent (even those who are glad to have been brought into existence may be engaged in defective reasoning related to failure to consider the appropriate counterfactual ${ }^{58}$ ). In addition, there is no cost-free escape from the condition of existence bestowed upon one if it is not to one's liking. ${ }^{59}$ Asheel Singh argues that the hypothetical consent objection doesn't work because non-existers do not have preferences. ${ }^{60}$ Benatar takes a similar line: the bar for ending a life is set in a different place from the bar for beginning a life in part because the existent typically have an interest in continuing to exist, the potential existent have no interests at all. No life is worth starting even if one knew that one's child would subjectively evaluate her life extremely positively (as most of us are wont to do). But, once dragged into the nightmare of existence, Benatar says, some lives are worth continuing, even though they are awful, "even if objectively one would be better off dead." 61

Getting to this verdict requires a move from thinking about the objective quality of possible lives, to thinking (at least in part) about the perceived quality of actual

\footnotetext{
56 Kirsten Egerstrom, "Review of The Human Predicament: A Candid Guide to Life's Biggest Questions by David Benatar," The Philosophers' Magazine, Vol. 78 ( $3^{\text {rd }}$ quarter, 2017): 111-112, p. 112.

57 Asheel Singh, "The Hypothetical Consent Objection to Anti-Natalism," Ethical Theory and Moral Practice, Vol. 21 (2018): 1135-50, p. 113.

58 David Benatar, "To Be or Not to Have Been? Defective Counterfactual Reasoning About One's Existence," The International Journal of Applied Philosophy, Vol. 15, No. 2 (2001): 255-266.

59 Seana Valentine Shiffrin, "Wrongful Life, Procreative Responsibility, and the Significance of Harm," Legal Theory, Vol. 5 (1999): 117-48, p. 133.

60 Singh, op. cit., p. 1142.

61 Benatar, The Human Predicament, op. cit., p. 188.
} 
lives. This is entirely sensible: in some cases, the rationality of suicide based on the objective quality of one's life can be trumped by the perceived quality of one's life (at least in part because optimistic appraisals can themselves improve one's quality of life). If Sisyphus loves his stone pushing duties, who are we to say he should stop? As Benatar puts the point:

Although their overestimation of the quality of their lives is a kind of irrationality, their perception of the quality of their lives, even if mistaken, is obviously relevant to an all-things-considered appraisal of their failure to kill themselves. $^{62}$

As I tried to make clear at the outset, my aim is not to show that Benatar's antinatalism gets us to the claim that ceasing to exist is rationally required, only that it gets us to the claim that doing so is in one's best interests. To see the point consider Jackie, who is in a relationship as awful as Jill's, but nevertheless (due to selfdeception) appraises her relationship as pretty good. It could still be the case that it is better for Jackie to end the relationship, even if she does have false beliefs about its quality. Similarly, Benatar notes:

[T]here is a difference between a subjective assessment of one's wellbeing influencing the objective level and a subjective assessment determining the objective level. Even if an overly optimistic subjective assessment makes one's life better than it would otherwise be, it does not follow that one's life is actually going as well as one thinks it is. ${ }^{63}$

Even if there is a feedback loop in which our thinking our lives are better than they are actually makes our lives better, "this is not sufficient to obliterate the distinction between one's perceptions of the quality of one's life and one's actual quality of life." ${ }^{64}$ Pro-mortalism then, understood as the claim that it is better for each of us to cease to exist, is not defeated by the fact that many of us overestimate the quality of our lives. Even if it is the case that, under an ends-means conception of rationality, choosing to cease to exist is not on the table for most folk, that does not mean that it is not what is best for us. As Matej Sušnik points out, Benatar's claim that all human lives are appalling is taken to be a claim about life's actual quality, not a claim about how we perceive it. Sušnik suggests that this distinction can be extended to the question of lives worth continuing:

[I]t seems perfectly consistent to distinguish between somebody thinking his life is worth continuing and his life actually being worth continuing. Armed with this distinction, one can then insist that Benatar does not rule out the possibility that most people merely think that their lives are worth continuing but that no human life is actually worth continuing. ${ }^{65}$

\footnotetext{
62 Ibid., 188.

63 Ibid., 70-1.

64 Benatar, "Every Conceivable Harm", op. cit., p. 156.

65 Matej Sušnik, "Why Would Very Bad Lives Be Worth Continuing?" South African Journal of Philosophy, Vol. 39, No. 3 (2020): 285-95, p. 289.
} 
If the human predicament really is as bad as all that, then, from the objective point of view, lives are neither worth starting nor continuing. Unreliable subjective evaluations of the quality of one's life can stave off pro-mortalism understood as a claim about what is rationally required. But they cannot do this work when it comes to making a difference to the objective fact of whether a life is worth continuing. Defective evaluations notwithstanding, it is still better no longer to be.

\section{Back to Deprivation}

One thing that could be said in reply to the foregoing is that the awfulness of life does not get us to pro-mortalism because bringing forward one's death deprives one of future goods:

[I]t is quite possible to think that even a stage of life is very bad without thinking that it is bad enough to make death preferable. If one takes death to be an extremely serious harm then life has to be doing worse than very bad in order to make life preferable. ${ }^{66}$

There are two things to say to this. One is to refer to my earlier work and my reply to Benatar's response to it at the start of the paper, and note that Epicureanism about death has not been ruled out. And so it isn't the case that Benatar can-without further argument-rely on the claim that we are deprived by death to block pro-mortalism.

For those who find the idea of deprivation by death attractive I say this. On Benatar's view, there is much more bad than good in our lives. Even granting that we are deprived of future goods (which is bad), for most folk, the goods one is deprived of are far outweighed by the bads one avoids having to endure, after all, "while some lives are better than others, none are (noncomparatively or objectively) good."67 Indeed, as Egerstrom notes, even if we grant that ceasing to exist is called for only when one's quality of life falls below some threshold (given the harm of being deprived of future pleasures), it is unclear "how the average person's life-if it as terrible as Benatar claims it to be-can manage to make it above that threshold." $[\text { sic }]^{68}$ Benatar himself notes that "[i]f our lives are quite as bad as [he suggests], and if people were prone to see this true quality of their lives for what it is, they might be much more inclined to kill themselves." 69 At the very least, even accepting the deprivation account of death, ceasing to exist is the better option for most people.

\footnotetext{
66 Benatar, "Still Better Never to Have Been", op. cit., p. 150.

67 Benatar, The Human Predicament, op. cit., p. 67.

68 Egerstrom, op. cit., p. 112.

69 Benatar, Better Never to Have Been, op. cit., p. 69.
} 


\section{Conclusions}

I have argued that Benatar's anti-natalism gets us to pro-mortalism. I began by revisiting my earlier claim that the asymmetry got us to pro-mortalism, at least without ruling out Epicureanism about death. I replied to Benatar's response to that earlier argument. I then looked at Benatar's argument for anti-natalism from the quality of life. I argued that that position makes ceasing to exist the best option. I looked at three ways Benatar seeks to block the move from his anti-natalism to pro-mortalism and replied to each of them. To conclude, if Benatar is right about the human predicament, it is better for us to return whence we came.

Acknowledgements I am grateful to Nikk Effingham, Michael Rush, and Alastair Wilson for comments on an earlier draft of this paper. Many thanks also to the editors of this special issue - Oliver Hallich and Michael Hauskeller - for inviting me to write the paper and for their helpful comments on the penultimate version.

Open Access This article is licensed under a Creative Commons Attribution 4.0 International License, which permits use, sharing, adaptation, distribution and reproduction in any medium or format, as long as you give appropriate credit to the original author(s) and the source, provide a link to the Creative Commons licence, and indicate if changes were made. The images or other third party material in this article are included in the article's Creative Commons licence, unless indicated otherwise in a credit line to the material. If material is not included in the article's Creative Commons licence and your intended use is not permitted by statutory regulation or exceeds the permitted use, you will need to obtain permission directly from the copyright holder. To view a copy of this licence, visit http://creativecommons.org/licen ses/by/4.0/.

Publisher's Note Springer Nature remains neutral with regard to jurisdictional claims in published maps and institutional affiliations. 